\title{
Passive haemagglutination inhibition for quantitation of red cell associated IgG
}

\author{
H I ATRAH, J G TEMPLETON, R J CRAWFORD, G S GABRA, R MITCHELL \\ From the Glasgow and West of Scotland Blood Transfusion Service, Law Hospital, Carluke, Lanarkshire, \\ and the Haematology Unit, Department of Pathology, University Medical Buildings, Foresterhill, Aberdeen, \\ Scotland
}

SUMMARY Passive haemagglutination inhibition (PHI) was adapted to quantitate red cell associated IgG. Twenty one patients with autoimmune haemolytic anaemia (AIHA) had a raised red cell associated $\mathrm{IgG}$, mean $(\mathrm{SD})=5 \cdot 783(6 \cdot 183) \mathrm{ng} / 10^{6}$ red blood cell compared with that of 69 subjects with a red cell associated IgG of $0.433(0.349) \mathrm{ng} / 10^{6}$ red blood cell. Thirteen of 14 blood donors with a positive direct antiglobulin test (DAGT) had a normal red cell associated IgG. The only 을 blood donor with positive DAGT and raised red cell associated IgG had AIHA. Studies of red cell associated IgG in other groups of patients were also undertaken.

The technique is simple, does not require the use of sophisticated equipment, and is suitable as a routine test in hospital laboratories. The results of red cell associated IgG by PHI are reproducible and clinically relevant.

IgG coated red cells do not necessarily have a shortened survival. ${ }^{12}$ Autoimmune haemolysis occurs when the red cell associated IgG exceeds a critical level. ${ }^{34}$ Complete agglutination of red cells from normal healthy blood donors in the direct antiglobulin test (DAGT) can occur with red cell associated IgG well below the critical level for haemolysis, ${ }^{5}$ while the same test can be negative in some cases of severe autoimmune haemolytic anaemia (AIHA). ${ }^{6}$ Serological scoring of the DAGT, in addition to being subjective, bears little or no relation to the clinical importance of IgG coating of red cells. Red cell associated IgG, on the other hand, is a clinically relevant and objective measure of immunoglobulin coating. The measurement of red cell associated IgG is potentially useful for the assessment of the severity of immune haemolysis.

Various techniques have been adapted to quantitate the red cell associated IgG in normal and pathological states, ${ }^{7}$ but, most of these methods are complicated, time consuming, and expensive. Passive haemagglutination inhibition (PHI) is simple, inexpensive, and requires equipment that is generally available in most laboratories. The results have important clinical implications in patients with AIHA and blood donors with positive DAGT results.

Accepted for publication 3 December 1986

\section{Material and methods}

PATIENT AND DONOR RED CELLS

Red cells from the following groups of subjects were tested for red cell associated IgG: 69 normal blood donors; 21 patients with AIHA; 15 patients with hypogammaglobulinaemia; 14 normal blood donors with positive DAGT (IgG coating with or without complement); eight patients who had high dose intravenous immunoglobulin sampled before and after treatment; one rhesus $\mathrm{D}$ positive patient with idiopathic thrombocytopenic purpura (ITP) who was treated with anti-D intravenously. ${ }^{8}$

All cells were washed six times in physiological saline and suspended in phosphate buffered saline (PBS), pH 7.4, to a final concentration of no more than $50 \%$. Particular care was taken to remove the buffy coat layer between each successive wash. After being counted by an electronic particle counter (Coulter) the cells were frozen and the haemolysates containing the IgG released from the membrane were used for testing. Duplicates from 20 samples were used to investigate the effect of cotton wool filtration before preparation of the red cell haemolysate.

EXPERIMENTAL COATING OF RED CELLS Rhesus $D$ positive red cells with Anti-D

To assess whether PHI was sensitive enough to detect small differences in IgG coating one volume of packed group $\mathrm{O}$ red cells of various rhesus pheno- 
types ( $r r, R_{1} r, R_{1} R_{1}, R_{1} R_{2}$ and $R_{2} R_{2}$ ) were incubated with two volumes of incomplete anti-D (the standard reagent used for rhesus $\mathrm{D}$ typing) at $37^{\circ} \mathrm{C}$ for one hour. The cells were then washed and haemolysates were prepared from them as described above.

\section{Red cells from patients with hypogammaglobulinaemia} with group AB plasma

Red cell samples from 15 patients with hypogammaglobulinaemia were washed and divided in two aliquots. One set was the control and the other was incubated with three volumes of $\mathrm{AB}$ plasma at $37^{\circ} \mathrm{C}$ for one hour. Both sets were then washed and processed as described above.

\section{INDICATOR RED CELLS}

These were prepared as described by Evans et a $l^{9}$ : washed packed group $\mathrm{O}$ human red cells $(0.4 \mathrm{ml}), 9 \mathrm{ml}$ PBS, $\mathrm{pH} 7 \cdot 4$, and $1 \mathrm{ml}$ pooled normal human serum were stired gently at room temperature. One millilitre of $2.5 \%$ glutaraldehyde was added slowly (15 minutes) and mixing was continued for 60 minutes before the cells were washed four times in saline. The coated cells at a concentration of $1 \%$ in PBS can be used satisfactorily for up to two weeks; longer storage may be achieved using Alsever's solution.

Serially diluted monospecific anti-IgG (Scottish Antibody Production Unit) $(30 \mu \mathrm{l})$ was mixed with an equal volume of red cell haemolysate in a round bottom microtitre plate (Cooke) and incubated for one hour at $20^{\circ} \mathrm{C}$. One drop of indicator cells was added to each well. After a short period of mixing on an agitator the plates were incubated for a further hour at the same temperature and finally examined for passive haemagglutination. A saline control was always included to establish the end point at which agglutination was inhibited. Dilutions of an IgG of known concentration were set up with each batch of tests and a standard line was constructed by plotting agglutination end point against IgG concentration. This was linear over the range $100 \mathrm{ng} / \mathrm{ml}$ to $5000 \mathrm{ng} / \mathrm{ml}$. The concentrations of $\mathrm{IgG}(\mathrm{ng} / \mathrm{ml})$ in the haemolysates were obtained from the graphs. The final results of red cell associated IgG were deduced from the latter figures and the red cell counts, and expressed as nanograms (ng) per $10^{6}$ red blood cells.

\section{Results}

The mean (SD) for red cell associated IgG of 69 normal blood donors was $0.433(0.349) \mathrm{ng} / 10^{6}$ red blood cell. An upper limit of $1 \cdot 131 \mathrm{ng} / 10^{6}$ red blood cells (mean $+2 \mathrm{SD}$ ) can be regarded as normal.

Red blood cells from 14 donors with positive DAGT results were tested; only one donor had an increased red cell associated $\mathrm{IgG}$ at $2 \mathrm{ng} / 10^{6}$ red blood cell, and all the rest were within the normal limit. The mean red cell associated IgG for the group was 0.484 $(0.467) \mathrm{ng} / 10^{6}$ red blood cell. There was no statistical difference $(p<0.5)$ between this group and the normal blood donors. Fig 1 compares the red cell associated IgG of normal blood donors, blood donors with positive DAGT, and patients with AIHA.

All patients with AIHA (except one) had raised red cell associated $\mathrm{IgG}$ values, with a mean of 5.783 $(6 \cdot 183) \mathrm{ng} / 10^{6}$ red blood cells. The difference between the red cell associated IgG of this group and that of the normal donors was highly significant ( $p>0.001$ ). Table 1 compares the red cell associated IgG and the serological scoring of the DAGT results of patients with AIHA and blood donors with positive DAGT results.

Fifteen patients with hypogammaglobulinaemia were studied. Seven were maintained on intramuscular immunoglobulin injections, and eight patients were treated with intravenous immuno-

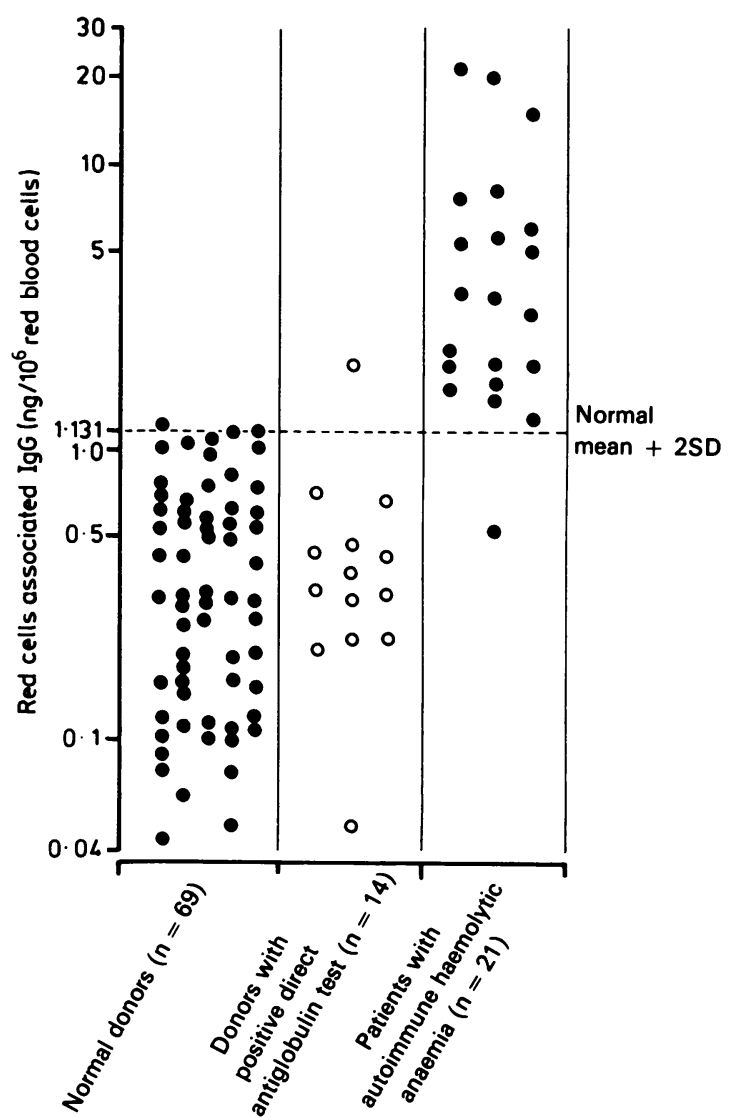

Fig 1 Red cell associated IgG of normal donors, donors with positive DAGT results, and patients with AIHA. 
Table 1 Comparison of red cell associated IgG and scoring of DAGT results (using anti-IgG) of patients with AIHA and blood donors with positive DAGT results

\begin{tabular}{|c|c|c|c|c|}
\hline \multirow[b]{2}{*}{ Case No } & \multicolumn{2}{|l|}{ Patients with AIHA } & \multicolumn{2}{|c|}{ Donors with positive $D A G T$ results } \\
\hline & $\begin{array}{l}\text { Red cell associated } \lg G \\
\left(\mathrm{ng} / 10^{6} \mathrm{RBC}\right)\end{array}$ & $D A G T$ score & $\begin{array}{l}\text { Red cell associated IgG } \\
\text { (ng/10 } 10^{6} \text { red blood cell) }\end{array}$ & $D A G T$ score \\
\hline $\begin{array}{l}1 \\
2 \\
3 \\
4 \\
5 \\
6 \\
7 \\
8 \\
9 \\
10 \\
11 \\
12 \\
13 \\
14 \\
15 \\
16 \\
17 \\
18 \\
19 \\
20 \\
21\end{array}$ & $\begin{array}{c}21.818 \\
20.714 \\
15.873 \\
8.196 \\
7.5 \\
5.857 \\
5.773 \\
5.476 \\
5.205 \\
3.687 \\
3.557 \\
3.007 \\
2.267 \\
2.94 \\
1.944 \\
1.941 \\
1.743 \\
1.621 \\
1.449 \\
1.277 \\
0.535\end{array}$ & $\begin{array}{l}++ \\
+++ \\
++ \\
+ \\
+ \\
++ \\
+++ \\
\text { Complete } \\
++ \\
+++ \\
++ \\
+++ \\
+++ \\
+ \\
+ \\
++ \\
+++ \\
+ \\
++++ \\
+ \\
++\end{array}$ & $\begin{array}{l}2 \\
0.699 \\
0.663 \\
0.476 \\
0.433 \\
0.424 \\
0.373 \\
0.326 \\
0.317 \\
0.304 \\
0.229 \\
0.228 \\
0.226 \\
0.081\end{array}$ & $\begin{array}{l}++++ \\
\text { Not recorded } \\
++++ \\
\text { Not recorded } \\
+++ \\
++ \\
+++ \\
\text { Not recorded } \\
+++ \\
\text { Not recorded } \\
++ \\
++ \\
++ \\
++\end{array}$ \\
\hline
\end{tabular}

globulin infusions. Table 2 shows the red cell associated IgG before and after incubation with $\mathrm{AB}$ plasma, the type of immunoglobulin treatment, and the serum IgG values of all patients. The mean red cell associated IgG for the group was low in comparison with that of normal blood donors $(0.05>p$ $>0.02$ ). The mean red cell associated IgG for the group receiving intramuscular injections was lowest $(0.02>p>0.01)$, and there was a significant rise of the red cell associated $\operatorname{IgG}(0.01>p>0.001)$ of all except one of the samples after incubation with $\mathrm{AB}$ plasma.
All eight patients who received high dose intravenous Ig (Protein Fractionation Centre of the Scottish National Blood Transfusion Service) had normal red cell associated IgG before treatment (table 3 ). Seven patients were given a total of $2 \mathrm{~g} / \mathrm{kg}$ intravenous Ig each over two to five days in the course of treatment of idiopathic thrombocytopenic purpura. The eighth patient received $0.9 \mathrm{~g} / \mathrm{kg}$ intravenous $\mathrm{Ig}$ daily for five days for the treatment of aplastic anaemia. ${ }^{10}$ All patients had a pronounced increase in their serum IgG and a significant rise in red cell associated $\operatorname{IgG}(0.05>p>0.02)$. Interestingly, the red

Table 2 Red cell associated IgG of patients with hypogammaglobulinaemia

\begin{tabular}{|c|c|c|c|c|}
\hline & Ig treatment & $S \operatorname{Ig} G(g / l)$ & $\begin{array}{l}\text { Red cell associated IgG } \\
\left(n g / 10^{6} \mathrm{RBC}\right)\end{array}$ & $\begin{array}{l}\text { Red cell associated IgG } \\
\text { (ng/106 red blood cell) after } \\
\text { incubation with } A B \text { plasma }\end{array}$ \\
\hline $\begin{array}{l}1 \\
2 \\
3 \\
4 \\
5 \\
6 \\
7 \\
8\end{array}$ & $\begin{array}{l}\text { Intravenous } \\
\text { Intravenous } \\
\text { Intravenous } \\
\text { Intravenous } \\
\text { Intravenous } \\
\text { Intravenous } \\
\text { Intravenous } \\
\text { Intravenous }\end{array}$ & $\begin{array}{l}3 \cdot 4 \\
6 \cdot 6 \\
6 \cdot 8 \\
3 \cdot 8 \\
3 \cdot 6 \\
4 \\
3 \cdot 1 \\
4\end{array}$ & $\begin{array}{l}0.209 \\
0.793 \\
0.423 \\
0.428 \\
0.812 \\
0.198 \\
0.06 \\
0.036\end{array}$ & $\begin{array}{l}0.85 \\
0.815 \\
1.695 \\
0.6 \\
1 \\
0.59 \\
0.493 \\
0.065\end{array}$ \\
\hline Mean (SD) & & $4 \cdot 41(1 \cdot 44)$ & $0.37(0.303)$ & $0.764(0.47)$ \\
\hline $\begin{array}{l}9 \\
10 \\
11 \\
12 \\
13 \\
14 \\
15\end{array}$ & $\begin{array}{l}\text { Intramuscular } \\
\text { Intramuscular } \\
\text { Intramuscular } \\
\text { Intramuscular } \\
\text { Intramuscular } \\
\text { Intramuscular } \\
\text { Intramuscular }\end{array}$ & $\begin{array}{l}1 \cdot 5 \\
1 \cdot 6 \\
2 \cdot 3 \\
4 \cdot 2 \\
2 \cdot 8 \\
3 \cdot 5 \\
2 \cdot 8\end{array}$ & $\begin{array}{l}0 \cdot 1 \\
0 \cdot 15 \\
0 \cdot 126 \\
0.082 \\
0 \cdot 08 \\
0 \cdot 059 \\
0.028\end{array}$ & $\begin{array}{l}0.19 \\
0.074 \\
1 \cdot 768 \\
0.21 \\
0 \cdot 119 \\
0.49 \\
0 \cdot 129\end{array}$ \\
\hline Mean (SD) & & $2.7(0.98)$ & $0.089(0.041)$ & $0.426(0.6)$ \\
\hline Overall (SD) & & $3.6(1 \cdot 5)$ & $0.239(0.26)$ & $0.606(0.547)$ \\
\hline
\end{tabular}

Red cell associated IgG incubation with $A B$ plasma

0.8

0.6

0.06

0.47

1.768

0.49

$0.426(0.6)$

\section{$\frac{3}{0}$ 으 $\Rightarrow$

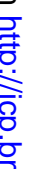


Table 3 Serum and red cell associated IgG before and after treatment with high dose intravenous Ig

\begin{tabular}{|c|c|c|c|c|}
\hline \multirow[b]{2}{*}{ Case No } & \multicolumn{2}{|l|}{ Serum $\operatorname{Ig} G(g / l)$} & \multicolumn{2}{|c|}{ Red cell associated $\operatorname{lgG}\left(\mathrm{ng} / 10^{6}\right.$ red blood cell $)$} \\
\hline & Before treatment & After treatment & Before treatment & After treatment \\
\hline $\begin{array}{l}1 \\
2 \\
3 \\
4 \\
5 \\
6 \\
7 \\
8\end{array}$ & $\begin{array}{l}4 \cdot 37 \\
10 \cdot 3 \\
9 \cdot 5 \\
9 \cdot 4 \\
8 \cdot 71 \\
9 \\
8 \cdot 9 \\
8\end{array}$ & $\begin{array}{l}22 \cdot 8 \\
35 \cdot 8 \\
18 \cdot 3 \\
26 \\
37 \cdot 6 \\
19 \cdot 5 \\
33 \cdot 6 \\
26 \cdot 8\end{array}$ & $\begin{array}{l}0.201 \\
0.113 \\
0.265 \\
0.041 \\
0.043 \\
0.308 \\
0.243 \\
0.07\end{array}$ & $\begin{array}{l}1.469 \\
0.338 \\
0.426 \\
0.056 \\
0.35 \\
0.808 \\
0.406 \\
0.53\end{array}$ \\
\hline After 7 days & & $34 \cdot 7$ & & 1.479 \\
\hline After 14 days & & & & 0.913 \\
\hline
\end{tabular}

cell associated IgG of the patient with aplastic anaemia was $0.07 \mathrm{ng} / 10^{6}$ red blood cell before treatment; it rose to $0.52 \mathrm{ng} / 10^{6}$ red blood cell after two doses of treatment, and a maximum of $1.479 \mathrm{ng} / 10^{6}$ red blood cell was attained on the seventh day, at which time the patient's red cells were DAGT positive. On the fourteenth day the red cell associated IgG had fallen to $0.913 \mathrm{ng} / 10^{6}$ red blood cell.

Red cell associated IgG increased in all samples of various $R$ h phenotypes after incubation with anti-D. The difference in red cell associated IgG before and after sensitisation for rr cells was considered to be non-specific and this value was subtracted from that for each $\mathrm{RhD}$ positive cell to give a corrected difference (table 4).

Repeated meticulous washing and removal of the buffy coat at each washing step considerably reduced the white cell and platelet counts. These counts and the red cell associated IgG, however, were marginally lower in the cotton wool filtered, compared with the non-filtered, aliquots.

The lower limit of detectability of IgG in the haemolysates ranged from 80 to $300 \mathrm{ng} / \mathrm{ml}$. One sample was stored frozen and its red cell associated IgG was assayed several times with every batch of samples (10 batches) to a total of 42 measurements. The mean value was $0.452(0.071) \mathrm{ng} / 10^{6}$ red blood cells and the coefficient of variation (the percentage of the SD to the mean) was $15.8 \%$. Intrabatch variation ranged from 0 to $20 \%$.

\section{Discussion}

Red cells from healthy subjects carry a small amount of IgG which is not detectable by the standard serological DAGT. This was quantitated by the PHI technique and an upper level of $1 \cdot 131 \mathrm{ng} / 10^{6} \mathrm{red}$ blood cell can be regarded as normal. Unlike the methods of other studies, we expressed the red cell associated IgG as $\mathrm{ng} / 10^{6}$ red blood cells rather than molecules of IgG per red cell because the latter implied a degree of sensitivity and precision beyond the reach of assays of this kind. ${ }^{11}$

All of the patients with AIHA had raised red cell associated IgG except one. No clinical details were available, and it is conceivable that this normal result may have been influenced by treatment. One patient with severe AIHA (case 4, table 1) had a negative DAGT result. The red cell associated IgG of the DAGT negative sample was $7 \cdot 482 \mathrm{ng} / 10^{6}$ red blood cell. The DAGT subsequently became positive and the red cell associated IgG remained more or less unchanged at $8 \cdot 196 \mathrm{ng} / 10^{6}$ red blood cell. It is not known why the DAGT was negative initially; nevertheless, measurement of red cell associated IgG may be a useful diagnostic tool to establish the autoimmune nature of haemolysis in such cases.

Red cells from all blood donors with positive DAGT results were coated with IgG within the normal range except one with a red cell associated IgG of $2 \mathrm{ng} / 10^{6}$ red blood cell. As this value is within the

Table 4 Red cell associated IgG of different rhesus phenotypes before and after incubation with anti-D

\begin{tabular}{|c|c|c|c|c|}
\hline \multirow[b]{2}{*}{ Phenotype } & \multicolumn{2}{|c|}{ Red cell associated $\operatorname{lgG}\left(\mathrm{ng} / 10^{6}\right.$ red blood cell) } & \multirow[b]{2}{*}{ Difference } & \multirow[b]{2}{*}{ Corrected difference } \\
\hline & Before incubation & After incubation & & \\
\hline $\begin{array}{l}r r \\
R_{1} r \\
R_{1} R_{1} \\
R_{1} R_{2} \\
R_{2} R_{2}\end{array}$ & $\begin{array}{l}0 \cdot 164 \\
0.556 \\
0.107 \\
0.538 \\
0.355\end{array}$ & $\begin{array}{l}0.813 \\
1.549 \\
1.111 \\
1.704 \\
3.725\end{array}$ & $\begin{array}{l}0.649 \\
0.993 \\
1.004 \\
1.166 \\
3.7\end{array}$ & $\begin{array}{l}0.344 \\
0.355 \\
0.517 \\
2.721\end{array}$ \\
\hline
\end{tabular}


range of red cell associated IgG of patients with AIHA the donor was recalled for investigation. He proved to have AIHA. He was treated and eventually underwent splenectomy. Subsequent follow up showed clinical and haematological improvement. None of the other donors has presented to date with evidence of immune haemolysis (some of them have even donated blood again since then). Measurement of red cell associated IgG, therefore, can identify the clinically relevant IgG coating of red cells. No relation was found between results of the red cell associated IgG and the serological scores of the DAGT (table 1).

Szymanski et al $^{12}$ found that eight patients with hypogammaglobulinaemia of varied aetiologies had subnormal IgG coating of red cells, but they were not able to show a significant rise following incubation with plasma. They also found raised IgG coating of red cells from patients with myeloma and chronic inflammation. The red cell associated IgG of all our patients with hypogammaglobulinaemia (except one) rose significantly following incubation with $\mathrm{AB}$ plasma. We have also found that when hypergammaglobulinaemia was induced in eight patients by high dose intravenous Ig, the red cell associated IgG rose significantly and that the rise was dose related in one patient who had multiple assays during treatment.

The $R h D$ positive patient with refractory idiopathic thrombocytopenic purpura, who was treated with anti-D, had raised red cell associated IgG before treatment (possibly due to two earlier courses of high dose intravenous Ig). The in vivo coating with anti-D further increased the red cell associated IgG (fig 2). Similarly, the results of the in vitro coating (table 4) show that PHI was sensitive enough to measure small differences in the specific uptake of anti-D by cells of different $R h$ phenotypes, presumably depending on the number of $D$ antigen sites. ${ }^{13}$

Platelets and leucocytes that had amounts of membrane bound IgG, ${ }^{14}{ }^{15}$ were not effectively eliminated by repeated washing of the red cells. Several samples were assayed with and without filtration. The filtered aliquots had marginally lower results, but the order of red cell associated IgG values of the samples remained unchanged in both groups. It is, however, preferable to filter all samples to obtain representative absolute values for the red cell associated IgG unaffected by contaminating platelets and leucocytes.

Any anticoagulant would be suitable for the collection of samples for the assay of red cell associated IgG by PHI. Red cells retrieved from clotted specimens can also be used. The lower limit of detectability of IgG ranged from 80 to $300 \mathrm{ng} / \mathrm{ml}$ of haemolysate. Quantitation of red cell associated IgG of heavily coated red cells can be reliably accomplished with a red cell count as low as $0.3 \times 10^{12} / 1$. Higher counts

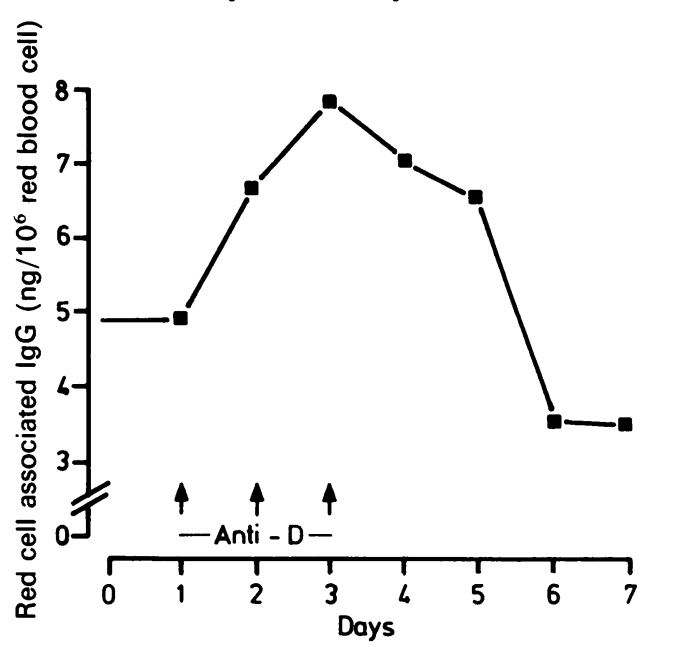

Fig 2 Red cell associated IgG of $A$ rhesus $D$ positive patient treated with anti-D.

were required, however, when the coating was nor- $\overrightarrow{0}$ mal, and a red cell count of $1.5-2 \times 10^{12} / 1$ is recom- $\stackrel{\infty}{V}$ mended for all samples to release enough IgG in the haemolysate for reliable quantitation. The purified IgG used to construct the standard line may be replaced by a standardised serum sample. Pooled concentrated human serum was used to coat the indicator cells, but ordinary normal human serum is equally satisfactory. Although distinction between positive and negative results is not difficult with the unaided eye, it can be made easier, if the microtitre plates are placed horizontally on a source of light such as a viewing box. The coefficient of variation of results by this method $(15 \%)$ is considerably lower than that of more sophisticated techniques. ${ }^{5}$

In conclusion, we have shown that PHI is a reliable technique for the quantitation of red cell associated IgG. The results are clinically relevant and raised values correlate closely with immune haemolysis in donors with positive DAGT results. Quantitation of red cell associated IgG by PHI may also provide an objective assessment of AIHA and its response to treatment. The simplicity of this method and its minimal demands on equipment and material should make it an attractive choice for the measurement of red cell associated IgG in many routine laboratories.

We acknowledge the secretarial help of Mrs S Balmer.

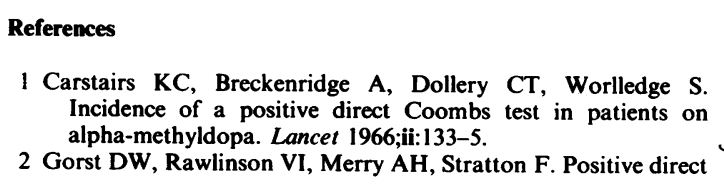

References

Carstairs KC, Breckenridge A, Dollery CT, Worlledge $S$. alpha-methyldopa. Lancet 1966;ii:133-5.

2 Gorst DW, Rawlinson VI, Merry AH, Stratton F. Positive direct 
antiglobulin test in normal individuals. Vox Sang 1980;38:99-105.

3 Meulen FW van der, Hart Mia van der, Fleer A, Borne AEG Kr von dem, Engelfriet $\mathrm{CP}$, Loghem JJ van. The role of adherence to human mononuclear phagocytes in the destruction of red cells sensitised with non-complement binding IgG antibodies. Br J Haematol 1978;38:541-9.

4 Stratton F, Rawlinson VI, Merry AH, Thomson EE. Positive direct antiglobulin test in normal individuals II. Clin Lab Haematol 1983;5:17-21.

5 Merry AH, Thomson EE, Rawlinson VI, Stratton F. A quantitative antiglobulin test for IgG for use in blood transfusion serology. Clin Lab Haematol 1982;4:393-402.

6 Gilliland BC, Baxter E, Evans RC. Red cell antibodies in acquired haemolytic anaemia with negative antiglobulin serum test. N Engl J Med 1971;285:252-6.

7 Schreibner AD. Quantitation of RBC-bound immunoglobulin and complement components. In: Chaplin $\mathrm{Jr} \mathrm{H}$, ed. Immune haemolytic anaemias. Edinburgh: Churchill Livingston, 1985:155-75.

8 Salama A, Kiefel V, Amberg R, Mueller-Eckhardt C. Treatment of autoimmune thrombocytopenic purpura with rhesus antibodies (anti-Rho [D]). Blut 1984;49:29-35.

9 Evans J, Steel M, Arthur E. A haemagglutination inhibition technique for detection of immunoglobulin in supernatants of human lymphoblastoid cell lines. Cell 1974;3(2): 153-8.

10 Atrah HI, Crawford RJ, Gabra GS, et al. Modulation of suppressor T-cells for the treatment of aplastic anaemia. Lancet 1985;ii:339-440.

11 Jeje MO, Blajchman MA, Steeves K, Horsewood P, Kelton JG. Quantitation of red cell-associated IgG using an immunoradiometric assay. Transfusion 1984;24:473-6.

12 Szymanski IO, Odgren PR, Normand LF, Snyder LM. Red blood cell associated IgG in normal and pathological states. Blood 1980;55:48-54.

13 Rochna E, Hughes-Jones NC. The use of purified ${ }^{125}$ I-labelled anti- $\gamma$ globulin in the determination of the number of $D$ antigen sites on red cells of different phenotypes. Vox Sang 1965;10:675-86.

14 Lougue G. Felty's Syndrome: granulocyte-bound immunoglobulin G and splenectomy. Ann Intern Med 1976;85:437-42.

15 Kelton JG, Giles AR, Neame PB, Powers P, Hageman N, Hirsh J. Comparison of two direct assays for platelet associated IgG (PAIgG) in assessment of immune and non-immune thrombocytopenia. Blood 1980;55:424-9.

Requests for reprints to: Dr HI Atrah, Haematology Unit, Department of Pathology, University Medical Buildings, Foresterhill, Aberdeen AB9 2ZD, Scotland. 